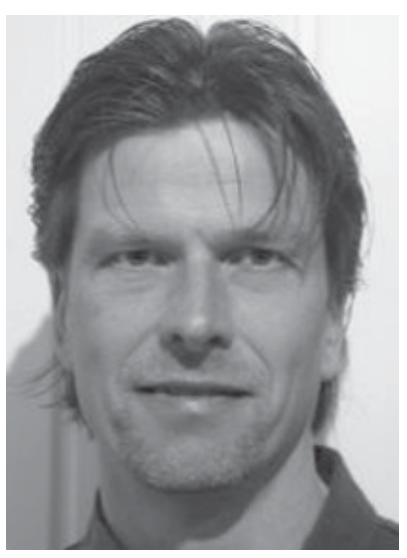

\title{
Sivistystä, tiedettä vai urheilua?
}

A

ikuiskasvatus on C-luokan tiedelehti. Tämä tarkoittaa ensinnäkin sitä, että lehdellämme on Euroopan mittakaavassa lähinnä paikallista ja alueellista merkitystä. Toiseksi lehtemme sisältöihin viitataan vain satunnaisesti Suomen ulkopuolella. Tähän taas on syynä se, että toimitamme Aikuiskasvatusta lähinnä oman maamme tiedeyhteisölle. Tiedelehtistatuksen edellytyksenä on, että tieteellisinä artikkeleina julkaistavat kirjoitukset on valittu, muokattu ja tarkistettu akateemisten standardien mukaisesti. Tiedeartikkeleina julkaistavat käsikirjoitukset ovat aina käyneet vähintään kahdella toisistaan riippumattomalla sokkoarvioijalla, joiden kommenttien perusteella niitä on muokattu ja paranneltu. Tämän tästä päädytään myös käsikirjoitusten hylkäämiseen, eli julkaisematta jättämiseen.

Yllä esitetyssä ei ole kyseessä päätoimittajan arvio, muistutus tai edes visio uuden vuoden 2008 kynnyksellä. Se perustuu Euroopan tiedesäätiön viime vuonna tuottamaan ja julkistamaan ihmistieteitä koskevan eurooppalaisen viiteindeksin rankkauskriteereihin. Kasvatustieteiden osalta viiteindeksi kattaa peräti 470 tiedelehteä ryhmiteltynä A-, B- ja C-kategorioihin. Suomesta edustettuina ovat Aikuiskasvatuksen ohella Kasvatus ja Lifelong Learning in Europe. Me kuulumme kaikki kolme samaan tuulipukuisten perässähiihtäjien C-ryhmään, joka on vasta lähdössä viimeiselle kierrokselle, kun kilpailun voittajat jo heittäytyvät hymyssä suin maalilinjan yli. Tässä ei auta edes LLine:in eurooppalaisuus tai englanninkielisyys. A- ja B-luokan status edellyttää maailmanlaajuista julkaisuareenaa ja lukijakuntaa. Aikuiskasvatuksen sarjassa voiton vie Penn State Universityssa, Amerikan Yhdysvalloissa harjoitteleva vajaa kuusikymppinen Adult Education Quarterly. Kovin kansainvälinen se ei kuitenkaan ole. Selkeä enemmistö siinä julkaistavista tieteellisistä artikkeleista on pohjoisamerikkalaisten tutkijoiden kirjoittamia.

Mutta tuuleen ei saa jäädä makaamaan. On noustava ylös ja jatkettava kilpailua, harjoiteltava kovempaa ja paremmin, kehityttävä ja tultava lopulta koko maailman parhaaksi - pudotettava Adult Education Quarterly kakkoseksi. Välineet, eli laatukäsikirjat, pistetasapainoilukortit ja penkinmerkkaukset ovat meidän kaikkien käytettävissä. Aloitetaan viimeksi mainitulla penkinmerkkauksella. Lehtemme pyrkii, sen missiota suoraan lainaten "lisäämään aikuiskasvatuksen tutkimuksen ja käytännön välistä vuoropuhelua”. Adult Education Quarterlyn mission suoran käännöksen perusteella se pyrkii ”edistämään aikuiskasvatukseen ja jatkuvaan koulutukseen liittyvää ymmärrystä sekä niiden käytäntöjä”. Eikö tässä olla ihan samalla asialla? Missioiden kuvauksista on kuitenkin tulkittavissa tietty akateeminen vivahde-ero, joka todentuu lehtien sisältörakennetta vertailtaessa. Aikuiskasvatuksessa julkaistaan, nimenomaan tutkimuksen ja käytännön vuoropuhelun edistämiseksi, erilaisia näkökulmia, puheenvuoroja ja tarvittaessa myös muun tyyppisiä kirjoituksia. Sama koskee kollegaamme Kasvatusta. Adult Education Quarterly:ssa puolestaan pidättäydytään kahteen perinteiseen osastoon; tiedeartikkeleihin ja kirja-arvioihin. Joku voisi todeta tämän julkaisutyylin olevan vanhanaikainen jopa kuivakka - ajas- 
sa, jossa verkkoon tuotetaan reaaliajassa "tieteellistä” tekstiä ja ajatustenvaihtoa, "koulutuksia” sekä vapaasti kaikkien käytössä ja täydennettävissä olevia vuorovaikutteisia "oppimateriaaleja."

Uusliberalistinen koulutuksen "kehittämisen” ohjaus- ja hallintaideologia, joka koskettaa koko suomalaista aikuiskasvatuksen kenttää - yliopistoista vapaaseen sivistystyöhön, henkilöstön kehittämisestä maahanmuuttajien kotouttamiskoulutukseen - on lähtökohtaisesti puhdasta retoriikkaa, korkealentoista kielipeliä. Metaforat ovat pääsääntöisesti peräisin luonnosta tai urheilukilpailuista. Yksi uusliberalismille ominainen piirre on tietoinen pyrkimys välttää suoritusten ja tavoitteiden kaikinpuolinen konkretisoiminen tai operationalisoiminen. Teollisesta tuotannosta suoraan kopioitujen mittareiden (laatu, vaikuttavuus, tehokkuus ja tuottavuus) operationalisoiminen jätetään aikuiskouluttajien tehtäväksi. Onkin mielestäni perusteltua esittää muutama tarkentava kysymys. Miten tehokasta on vapaa sivistys? Paljonko painaa huipputieteen tekemiseen vaadittava kriittinen massa? Mistä alkaa kansainvälisyys? Yksinkertaiselle pragmaatikolle kansainvälisyys merkitsee astumista Venäjän, Norjan tai Ruotsin rajan yli, yhteistyötä oman alan kollegojen kanssa meidän naapurimaissamme. Hyvänä ja ajankohtaisena esimerkkinä toimikoon Kansalais- ja työväenopistojen liiton tämänvuotinen Tammiseminaari Pietarissa. Siellä puhuttiin mitä ilmeisimmin englantia. Kansainvälisyydessä ei ole sitä vapaan sivistystystyön tai aikuiskasvatuksen kentältä tarkasteltaessa mitään uutta tai innovatiivista. Sama koskee elinikäisen kasvatuksen/oppimisen ajatusta ja käsitettä. Kansansivistäjille se on kovin tuttu jo vuosisadan takaa. Kriittisen massan käsite on menettänyt täysin merkityksensä tietoverkkojen ajassa, jossa pystyn omasta työhuoneestani tarpeen vaatiessa olemaan reaaliaikaisessa ääni- ja kuvayhteydessä Adult Education Quarterly:n neljään toimittajaan.

Itse asiassa uusliberalismi on vanhaa liberalismia. Uusliberalistinen kilpailuretoriikka ja sen kaupittelemat välineet tieteenteon tai aikuiskoulutuksen kehittämiseksi ovat peräisin menneiltä ajoilta. Kilpailu, A-, B-, ja C-erät ja huipputulokset kuuluvat urheilukentille ja moottoriradoille, joissa ruumiita ja koneita viritellään teknologian keinoin yhä parempiin suorituksiin. Sivistyksen edistäminen ja tieteen tekeminen ovat hengen, eivät ruumiin kulttuuria. Sivistys on sanakirjan mukaan opin, tiedon ja taidon ohella ihmisen sisäistä kehittyneisyyttä ja kypsyyttä.

\section{Petri Salo}

psalo@abo.fi

P.S. European Reference Index for the Humanities rankkauslista ja sen perusteet löytyvät hankalan http://www.esf.org/research-areas/humanities/activities/ research-infrastructures/faq-sheet/scope-initial-lists.html osoitteen takaa. Kattavasta 470:n kasvatustieteellisen tiedelehden listasta puuttuu esimerkiksi journaali nimeltä Educational Management Administration \& Leadership ja Pedagogisk Forskning i Sverige. 